\title{
UPAYA MENINGKATKAN HASIL BELAJAR EKONOMI MELALUI METODE TUTOR SEBAYA KELAS XI MADRASYAH ALIYAH DI PALANGKA RAYA
}

\author{
ENDANG SRI SUYATI
}

Dosen Pada Fakultas Keguruan dan IImu Pendidikan Universitas Muhammadiyah Palangkaraya

\begin{abstract}
The purpose of this research were to know: (1) the activities of the students on Economy learning (2) whether there is or not the increasing outcomes of economy learning after implemented the peer tutor method.

Kind of this research method is the Classroom Action Research (CAR). The subjects in this research are all the students on class XI IPS 1 MA Darul Ulum Palangkaraya that amount 22 students who at one time used as a sample. Data analysis based on the result of the cycle on the learning process. From the result of the research concluded that (1) there is increased activity of learners in the learning economy by applying the method of peer tutoring in class XI IPS 1 MA Darul Ulum Palangkaraya be better, learners are more active and participate in the learning process, so that students are able to express their opinions both orally and in writing. (2) There is the increasing of economy learning outcomes by implementing peer tutoring method in class XI IPS 1 MA Darul Ulum Palangkaraya. In the cycle I can be determined percentage of pre- acquisition results of the test are learners who completed $18.18 \%$ (4 people) and students who did not complete $81.82 \%$ (18 people) with an average value is 49.27. As for the acquisition of the results of the cycle I of activity percentage of students is $72.72 \%$ with an average of 28.28 , while the acquisition of learning outcomes of students is $68.18 \%$ with an average of 60.68 . In the cycle II of acquisition activity the percentage of students is $90.9 \%$ with an average of 35.68 , while the acquisition of learning outcomes of students is $95.45 \%$ with an average of 84.45 . There is an increase in learning outcomes of pre-test to the cycle I is $50 \%$, while from the cycle I to the cycle I there is an increase in learning outcomes as many as $27.27 \%$. This can be concluded that there is an increase in learning by using of peer tutoring method on students of class XI IPS 1 MA Darul Ulum Palangkaraya.
\end{abstract}

Keywords : learning outcomes, economy, students activity, peer tutoring method

\section{ABSTRAK}

Penelitian ini bertujuan mengetahui (1) aktivitas peserta didik dalam pembelajaran Ekonomi dan (2) ada tidaknya peningkatan hasil belajar Ekonomi setelah menerapkan metode tutor sebaya. Jenis penelitian ini adalah Penelitian Tindakan Kelas (PTK). Subjek penelitian ini adalah peserta didik kelas XI IPS-1 MA Darul Ulum Palangka Raya yang berjumlah 22 orang peserta didik yang sekaligus dijadikan sebagai sampel penelitian. Teknik analisis data didasarkan pada hasil siklus pada saat proses pembelajaran.

Dari hasil penelitian disimpulkan bahwa: (1) Terdapat peningkatan aktivitas peserta didik dalam pembelajaran Ekonomi dengan menerapkan metode tutor sebaya pada kelas XI IPS-1 MA Darul Ulum Palangka Raya menjadi lebih baik. Peserta didik lebih aktif dan lebih berpartisipasi dalam proses pembelajaran, Sehingga peserta didik mampu mengemukakan pendapatnya baik secara lisan maupun tertulis. (2) ada peningkatan hasil belajar Ekonomi setelah menerapkan metode tutor sebaya pada peserta didik kelas XI IPS-1MA Darul Ulum Palangka Raya. Pada siklus I dapat diketahui perolehan hasil persentase pre-test terdapat peserta didik yang tuntas $18,18 \%$ (4 orang) dan peserta didik yang tidak tuntas $81,82 \%$ (18 orang) dengan nilai rata-rata yaitu 49,27 . perolehan hasil pada siklus I jumlah persentase aktivitas peserta didik adalah $72,72 \%$ dengan rata- rata 28,28 sedangkan perolehan hasil belajar peserta didik adalah $68,18 \%$ dengan rata-rata 60,68 . Pada siklus II perolehan hasil persentase aktivitas peserta didik adalah $90,9 \%$ dengan rata-rata 35,68 sedangkan hasil belajar peserta didik adalah $95,45 \%$ dengan rata-rata 84,45 . Ada peningkatan hasil belajar dari pretest ke siklus I sebanyak $50 \%$ sedangkan dari siklus I ke siklus II ada peningkatan hasil belajar sebanyak $27,27 \%$. Disimpulkan bahwa ada peningkatan belajar menggunakan metode tutor sebaya pada peserta didik kelas XI IPS-1 MA Darul Ulum Palangka Raya.

Kata Kunci: hasil belajar, ekonomi, aktivitas peserta didik, metode tutor sebaya 


\section{PENDAHULUAN}

Keberadaan metode pembelajaran diperlukan untuk membantu tugas- tugas guru. Guru memiliki peran yang sangat penting guna menciptakan kondisi pembelajaran yang efektif sehingga memungkinkan proses pembelajaran dapat mencapai tujuan yang baik. Salah satu kompetensi profesional yang harus dimiliki seorang guru adalah guru harus dapat memilih, mengembangkan dan menggunakan metode pembelajaran. Hal ini penting karena dapat membantu para guru dan staff pengajar dalam menyampaikam pesan pembelajaran lebih cepat dan lebih mudah ditangkap oleh para peserta didik. Metode pembelajaran memiliki kekuatankekuatan yang positif dan sinergi yang mampu merubah sikap dan tingkah laku, hasilnya mereka kearah perubahan yang kreatif dan dinamis. Sehubungan dengan hal itu, peran metode seperti Tutor Sebaya sangat dibutuhkan dalam pembelajaran dimana dalam perkembangan saat ini metode bukan lagi dipandang sekedar alat bantu tetapi merupakan bagian yang integral dalam sistem pendidikan dan pembelajaran.

Penggunaan Tutor Sebaya sebagai metode pembelajaran merupakan konsep pembelajaran yang menekankan pada keterkaitan antara materi pembelajaran dengan peserta didik. Agar tujuan pengajaran tercapai sesuai dengan yang telah dirumuskan oleh pendidik, maka seorang pendidik perlu mengetahui dan mempelajari beberapa metode mengajar, serta mempraktekkan metode tersebut saat mengajar.

Menurut Ischak dan Warji (Suherman, 2004: 276) bahwa tutor sebaya adalah sekelompok peserta didik yang telah tuntas terhadap bahan pelajaran, memberikan bantuan kepada peserta didik yang mengalami kesulitan dalam memahami bahan pelajaran yang dipelajarinya. Kegiatan tutor sebaya bagi peserta didik merupakan kegiatan yang kaya akan pengalaman yang sebenarnya merupakan kebutuhan peserta didik itu sendiri, Tutor maupun yang ditutori sama-sama diuntungkan bagi tutor akan mendapat pengalaman sedangkan yang ditutori akan lebih kreatif dalam menerima pelajaran. Dengan demikian akan tercipta suasana pembelajaran yang menyenangkan sehingga peserta didik dapat mengoptimalkan potensi yang dimiliki dan hasil belajar ekonomi akan lebih meningkat.

Dari pengamatan yang dilakukan pada saat kegiatan observasi pada bulan Desember di Marasah Aliyah Darul Ulum Palangka Raya, terdapat beberapa permasalahan diantaranya: Pemahaman peserta didik yang tidak merata, dimana terdapat peserta didik yang cepat memahami penjelasan guru dan ada masih banyak peserta didik yang kurang memahami konsep yang disampaikan oleh guru. Kurangnya partisipasi peserta didik dalam pembelajaran di kelas, hal ini terlihat dari jarangnya peserta didik yang bertanya kepada guru bila tidak mengerti dan tidak jelas akan materi yang di sampaikan guru kecuali peserta didik tertentu saja. Banyak peserta didik yang kurang bersemangat dan cendrung bosan untuk mengikuti pelajaran ekonomi sehingga pada saat pembelajaran peserta didik biasanya tidak memperhatikan pembelajaran, banyak yang melamun dan melakukan aktifitas lain diluar pembelajaran. Perasaan bosan pada peserta didik dapat disebabkan oleh metode pembelajaran yang dilakukan oleh guru yang tidak bervariasi yaitu 
ceramah, tanyajawab, dan penugasan saja. Kondisi belajar peserta didik tersebut berdampak pada nilai tugas bahkan nilai UTS (Ujian Tengah Semester). Sehingga diperlukan upaya untuk meningkatkan hasil belajar IPS tersebut. Untuk itu peneliti merasa penggunaan metode tutor sebaya akan lebih tepat karena keadaan dan karakteristik peserta didik yang berbeda, karena peserta didik lebih nyaman bertanya kepada temannya dari pada kepada guru.

Menurut Djamarah dkk (2007: 120) yang menjadi petunjuk bahwa suatu proses belajar dianggap berhasil apabila: 1) Daya serap terhadap bahan pengajaran yang diajarkan mencapai prestasi tinggi, dan 2) Perilaku yang digariskan dalam tujuan pengajaran telah dicapai oleh peserta didik. Berdasarkan pendapat tersebut suatu proses belajar dianggap berhasil apabila pemahaman terhadap materi atau bahan ajar akan lebih dimengerti oleh peserta didik sehingga akan dapat menguasai pelajaran dan mencapai prestasi yang baik atau tinggi serta setiap tujuan pengajaran harus sesuai dalam penerapannya pada saat pembelajaran berlangsung, agar tujuan tersebut dapat dipahami dan dimengerti oleh peserta didik untuk mencapai suatu keberhasilan atau prestasi yang baik.

Secara rinci menurut Suryabrata (2004:1314), mengemukakan bahwa faktor-faktor yang mempengaruhi prestasi belajar meliputi: 1) Faktor luar: Lingkungan (alam dan sosial) dan instrumen, kurikulum, program sarana dan guru), 2) Faktor dalam: Fisiologis (fisiologis secara umum dan kondisi, panca indera) dan psikologis (minat, kecerdasan, bakat, motivasi, dan kemampuan kognitif). Sejalan dengan ini menurut Walgito (Djamarah, 2007: 78) bahwa: Faktor-faktor yang mempengaruhi hasil belajar peserta didik antara lain inteligensi, pribadi yang seimbang, dan kepercayaan pada diri. Dengan demikian jelas bahwa prestasi belajar ditentukan oleh berbagai faktor, tidak hanya berdasarkan kemampuan inteligensi saja tetapi faktor luar juga sangat menentukan.Dalam kegiatan belajarnya, peserta didik memerlukan perhatian orang tua untuk mengarahkannya agar tercapai hasil optimal. Selain itu, orang tua wajib membimbing dan menyediakan fasilitas serta menciptakan kondisi dan situasi belajar di rumah, memberi dorongan serta membimbing peserta didik dalam mengembangkan dirinya, kesemuanya itu tentu saja akan mempengaruhi terhadap hasil belajar peserta didik.

Menurut Soemarsono (2005: 20) Ruang Lingkup Pembelajaran Ekonomi di SMA dimulai dari masalah- masalah ekonomi yang terjadi di lingkungan kehidupannya yang terdekat hingga pada lingkungan yang terjauh. Adapun ruang lingkup pelajaran ekonomi di SMA adalah perilaku ekonomi dan kesejahteraan yang secara rinci mencakup aspek-aspek sebagai berikut: 1) berekonomi, 2) ketergantungan, 3) spesialisasi dan pembagian kerja, 4) perkoperasian, 5) kewirusahaan, dan 6) pengelolaan keuangan perusahaan.

Menurut Isjoni (Uno, 2008: 146) model pembelajaran merupakan strategi yang digunakan guru untuk meningkatkan motivasi belajar, sikap belajar dikalangan peserta didik, maupun berpikir kritis, memiliki ketrampilan sosial, dan pencapaian hasil belajar yang lebih optimal. Melakukan strategi pembelajaran secara dini dalam upaya mengatisipasi ksesulitan-kesulitan yang dihadapi peserta didik agar tidak berdampak lebih jauh 
terhadap pengaruh yang cukup signifkan terhadap kemampuan peserta didik dalam menguasai kompotensi yang seharusnya dicapai dan berdampak pada hasil belajar peserta didik, salah satu mtode yang diduga mampu membuat suasana pembelajaran yang menarik dan menyenangkan serta dapat membantu kesulitan belajar peserta didik adalah metode tutor sebaya, melalui metode ini peserta didik secara terbuka dan interaktif dibawah bimbingan guru, sehingga terpacu untuk menguasai bahan ajar yang diberikan guru sesuai standar.

Tutor sebaya secara harafiah berasal dari dua kata yaitu tutor dan baya. Dalam kamus bahasa Indonesia, tutor didefenisikan orang yang memberi pelajaran (membimbing) kepada seorang atau sejumlah kecil peserta didik, sedangkan sebaya adalah sama atau hampir sama umur. Pada pembelajaran dengan menggunakan metode tutor sebaya peserta didik yang berperan sebagai tutor akan terlebih dahulu dibekali dengan materi yang akan disampaikan oleh guru. Pembekalan materi ini dilakukan diluar jam pelajaran, tetapi dalam pembelajaran berlangsung guru juga menerangkan materi tersebut secara singkat hanya pokok bahasanya saja. Ada beberapa teori yang mendasari strategi pembelajaran tutor sebaya. Menurut Ali, (2004: 49) bahwa metode belajar yang paling baik adalah mengajarkan kepada orang lain. Oleh karena itu, pemilihan model tutor sebaya sebagai strategi pembelajaran akan sangat membantu peserta didik dalam mengerjakan materi kepada teman-temanya. Sedangkan Setiawan dkk (Mahmud 2011: 97) mengemukakan bahwa tutor sebaya adalah peserta didik yang pandai memberikan bantuan belajar kepada peserta didik yang kurang pandai. Bantuan tersebut dapat dilakukan teman-teman diluar sekolah. Mengingat bahwa peserta didik pokok dalam pengajaran. Menurut Arikunto (2010: 112), tujuan dari tutor sebaya adalah: Mengajar teman sebaya memberikan kesempatan pada peserta didik mempelajari sesuatu dengan baik. Pada waktu yang sama ia menjadi narasumber bagi yang lain. Strategi berikut merupakan cara praktis untuk menghasilkan teman sebaya dikelas. Strategi tersebut juga memberikan tambahan-tambahan apabila mengajar dilakukan oleh peserta didik. Beberapa ahli percaya bahwa suatu mata pelajaran benar-benar dikuasai hanya apabila seorang peserta didik mampu mengajar pada peserta didik lain.

Menurut Arikunto (2010: 130-135) kelebihan Tutor Sebaya adalah: 1) kemudahan menyampaikan informasi karena menggunakan bahasa yang sama dengan teman sebayanya, 2) teman sebaya lebih terbuka mengemukakan kesulitan materi, 3) suasana lebih santai sehingga perasaan takut atau enggan akan hilang, 4) hubungan sosial antar peserta didik lebih kuat sehingga mempererat persahabatan, 5) perbedaan karakteristik lebih diperhatikan, 6) pemahaman konsep terhadap materi lebih tercapai, dan 7) melatih tanggung jawab serta mendorong kreativitas peserta didik. Pendapat lain menurut Ahmadi dan Supriyono (2008: 184), dengan tutor ini ada kebaikanya,yaitu sebagai berikut: 1) adannya hubungan yang lebih dekat dan akrab, 2) tutor sendiri kegiatannya merupakan pengayaan dan menambah motivasi belajar, dan 3) dapat meningkatkan rasa tanggung jawab dan kepercayaan diri. 
Menurut Arikunto (2010: 167), bahwa langkah-langkah tutor sebaya adalah: 1) peserta didik dikelompokan menjadi kelompok kecil yang heterogen yang terdiri dari 4-5 peserta didik. Peserta didik yang bertindak sebagai tutor sebaya dipilih sesuai dengan criteria yang telah ditentukan guru, 2) masing masing kelompok diberi tugas mempelajari satu bab materi. Setiap kelompok dipandu oleh peserta didik yang telah dipilih menjadi tutor yang telah mendapatkan petunjuk, bimbingan materi dari guru, 3) tutor menyampaikan permasalahan kepada guru pembimbing apabila ada materi ajar yang belum dikuasai, 4) tutor melaporkan perkembangan akademis kelompoknya kepada guru pembimbing pada setiap materi yang dipelajar, peran guru dalam metode tutor sebaya hanyalah sebagai fasilitator, dan 5) melakukan pembahasan soal diskusi sebagi tugas kelompok. Setiap anggota kelompok mencocokan hasil jawaban soal diskusi yang dikerjakan dengan bantuan tutor secara aktif mengeluarkan pendapat saat pembahasan.

\section{METODE PENELITIAN}

Penelitian ini dilaksanakan pada bulan Desember 2013 sampai dengan Juni 2014, adapun jadwal penelitian ini sebagaimana terlampir. Dalam penelitian ini peneliti mengambil tempat di MA Darul Ulum Palangka Raya Tahun Pelajaran 2013/2014.

Jenis penelitian yang digunakan adalah Penelitian Tindakan Kelas (PTK), yaitu penelitian praktis yang dimaksudkan untuk memperbaiki pembelajaran di kelas. Penelitian ini merupakan upaya guru atau praktisi dalam bentuk berbagai kegiatan yang dilakukan untuk memperbaiki mutu pembelajaran di kelas.
Penelitian dilaksanakan di MA Darul Ulum Palangka Raya pada peserta didik kelas XI IPS 1, dimana subjek penelitiannya adalah peserta didik di kelas XI IPS 1 MA Darul Ulum Palangka Raya Tahun Pelajaran 2013/2014.

Tabel 1. Subjek Penelitian

\begin{tabular}{|c|c|c|c|}
\hline \multirow{2}{*}{ Kelas } & \multicolumn{2}{|c|}{ JenisKelamin } & \multirow{2}{*}{ Jumlah } \\
\cline { 2 - 3 } & Laki-laki & Perempuan & \\
\hline XI IPS 1 & 10 & 12 & 22 \\
\hline
\end{tabular}

Sumber Data : TU MA DarulUlum Palangka Raya 2014

Adapun rancangan dalam penelitian ini terdiri dari empat komponen yaitu perencanaan, pelaksanaan tindakan, observasi, dan refleksi.Keempat komponen tersebut dipandang sebagai suatu siklus.

Teknik pengumpulan data yang digunakan peneliti sebagai pedoman dalam penelitian ini untuk mengumpulkan data yang diperlukan adalah observasi dan dokumentasi.

Menurut Sukardi (2009: 78) "observasi adalah instrumen lain yang sering dijumpai dalam penelitian pendidikan". Observasi atau pengamatan yang digunakan peneliti sebagai salah satu cara untuk mengumpulkan data melalui pengamatan langsung dilapangan yang hasilnya dicatat sebagai hasil pengamatan lapangan.Datadata yang diamati dan menjadi fokus pengamatan adalah tentang hasil belajar peserta didik kelas XI IPS-1 MA Darul Ulum Palangka Raya, khususnya dalam upaya meningkatkan hasil belajar melalui metode Tutor sebayapada saat peserta didik melaksanakan kegiatan belajar ekonomi disekolah.Dalam rangka observasi, peneliti dalam penelitian ini menyaksikan secara langsung suatu kejadian mengenai masalah tersebut yang terjadi dalam proses kegiatan belajar mengajar dikelas 
mata pelajaran ekonomi. Sedangkan dokumentasi merupakan suatu teknik pengumpulan data dengan menghimpun dan menganalisis Dokumen-dokumen, baik dokumen tertulis, gambar maupun elektronik. Pada penelitian ini dokumen yang dipergunakan adalah dokumen tertulis berupa data prestasi belajar atau hasil belajar peserta didik dari nilai raport.

Menurut Arikunto (2010: 151) bahwa Instrumen penelitian adalah alat atau fasilitas yang digunakan oleh penelitian dalam mengumpulkan data agar pekerjaanya lebih mudah dan hasilnya lebih baik, dalam artian lebih cermat, langkapdan sistematis sehingga lebih mudah diolah. Dalam penelitian ini digunakan instrumen penelitian berupa pedoman observasi dan tes. Pedoman observasi berisi sebuah daftar jenis kegiatan yang mungkin timbul dan Pedoman observasi dibuat peneliti. Sedangkan Tes digunakan untuk menentukan sesuatu mengenai kedudukan atau predikat seseorang. Pengerjaanya juga khusus cara menjawab, situasi tertentu, waktu, dan prosedur tertentu pula. Menurut Arikunto (2010: 171) "Tes adalah instrumen yang disusun secara khusus karena mengukur sesuatu yang sifatnya penting dan pasti”. Sedangkan menurut Mahmud (2011: 185) "Tes adalah rangkaian pertanyaan atau alat lain yang digunakan untuk mengukur keterampilan, pengetahuan, intelegensi, kemampuan atau bakat yang dimiliki individu atau kelompok". Tes Awal (pretest) dan Tes Akhir (post test) peneliti ingin mengetahui adakah peningkatan hasil belajar peserta didik dengan menggunakan metode tutor sebaya. Berdasarkan beberapa pendapat di atas dapat disimpulkan bahwa tes adalah instrumen untuk mengukur suatu kemampuan yang dimiliki individu atau kelompok. Menurut Suharsimi (dalam Ade Kurniawan 2013:45) "sebuah instrumen dikatakan valid apabila mampu mengukur apa yang diinginkan dan dapat mengungkap data dari variabel yang diteliti”. Uji instrumen yang baik harus memenuhi dua persyaratan penting, yaitu valid dan reliable. Menurut Sudjono (Kurniawan 2013: 45) bahwa "validasi yang diteli dari segi isi tes itu sendiri sebagai alat belajar" yaitu sejauh mana tes hasil belajar sebagai alat pengukur hasil belajar peserta didik, isinya telah dapat mewakili secara representative terhadap keseluruhan materi atau bahan pelajaran yang seharusnya di teskan (diujikan). Biasanya validitas isi ditentukan melalui Profesional Jugdment, yaitu pendapat para ahli tentang isi materi tes, para ahli yang memutuskan valid atau tidak valid yaitu dengan meminta bantuan dengan 2 (dua) orang sebagai validator.

Kriteria ketuntasan hasil belajar pada proses pembelajaran dapat dinyatakan sebagai berikut: 1) Daya serap individual, seorang peserta didik dinyatakan tuntas belajar apabila telah mencapai skor > 60 dari skor maksimal 100, dan 2) Daya serap klasikal jika satu kelas dikatakan tuntas apabila terdapat skor minimal mencapai > $85 \%$ peserta didik yang telah mencapai skor 60 dari skor maksimal. Untuk melihat tingkat keberhasilan dari penelitian ini dengan indikator keberhasilan penelitian sebagai berikut: 1) peningkatan aktivitas peserta didik pada penelitian ini dapat ditentukan dari hasil observasi selama pembelajaran. Berdasarkan lembar observasi peserta didik tersebut skor minimal 10 dan skor maksimal adalah 40. Aktivitas peserta didik dikatakan meningkat total skor aktivitas peserta didik dalam pembelajaran mencapai 
jumlah $\geq 30$, dan secara klasikal jumlah peserta didik yang memiliki jumlah skor $\geq 30$ mencapai $40 \%$ dari jumlah seluruh peserta didik. Kriteria Ketuntasan Minimal (KKM) belajar yang ditetapkan oleh pihak sekolah MA Darul Ulum Palangka raya untuk mata pelajaran Ekonomi adalah 60. Indikator keberhasilan dalam penelitian ini ditunjukkan dengan perolehan nilai peserta didik di atas nilai KKM 60, dan 2) hasil yang diperoleh dari nilai post test mencerminkan kemampuan peserta didik untuk mengenal neraca lajur dengan menerapkan metode tutor sebaya. Penelitian ini dikatakan berhasil apabila hasil belajar peserta didik mencapai nilai ketuntasan individual $\geq 60$ dan secara klasikal terdapat $85 \%$ peserta didik yang memperoleh nilai $\geq 60$

\section{HASIL DAN PEMBAHASAN}

Berdasarkan tes uji kompetensi data awal pada pokok bahasan neraca lajur (kertas kerja) yang dilaksanakan pada hari Kamis tanggal 17 Mei 2014, di mana proses pembelajarannya dilakukan secara konvensional dan belum menerapkan metode Tutor sebaya, ternyata hasilnya kurang memuaskan, padahal guru sudah berupaya semaksimal mungkin menanamkan konsep pada materi tersebut. Hasil belajar yang diperoleh peserta didik pada tes awal ini dari 22 peserta didik yang memperoleh nilai KKM 60 ke atas hanya 4 orang $(18,18 \%)$, sedangkan yang memperoleh nilai di bawah 60 sebanyak 18 orang $(81,82 \%)$ dengan rata- rata 49,27 dan ketuntasan klasikal hasil belajar adalah 18,18\%. Konsep yang diterima peserta didik tentang materi neraca lajur (kertas kerja) masih belum tercapai artinya belum mencapai KKM meskipun materi yang diajarkan sudah dijelaskan berkali-kali, oleh karena itu dilakukan upaya perbaikan dengan mengidentifikasi kekurangan dari pembelajaran Ekonomi yang telah dilaksanakan di kelas XI IPS1 MA Darul Ulum Palangka Raya. Adapun upaya yang dilakukan untuk memperbaiki pembelajaran yaitu dengan menerapkan metode tutor sebaya diharapkan hasil belajar peserta didik dapat meningkat.

Data hasil belajar diperoleh dari hasil tes setelah selesai dilakukannya tindakan pada siklus I (post test). Hasil belajar yang diperoleh peserta didik pada tes akhir (post test) ini dari 22 peserta didik yang memperoleh nilai KKM 60 ke atas adalah 15 orang $(68,18 \%)$, sedangkan yang memperoleh nilai di bawah 60 adalah 7 orang $(31,82 \%)$ dengan rata-rata 60,68 dan ketuntasan klasikal hasil belajar adalah $68,18 \%$.

Aktivitas peserta didik dalam pembelajaran dengan persentase $72,72 \%$ sementara dengan indikator ketuntasan aktivitas belajar total skor minimal 10 dan skor maksimal 40 dimana diperoleh skor aktivitas peserta didik adalah 28,63\% di atas skor minimal. Aktivitas peserta didik dikatakan meningkat apabila skor total mencapai jumlah $\geq 30$, sedangkan secara klasikal jumlah peserta didik yang memiliki jumlah skor $\geq$ 30 mencapai $72,27 \%$. hanya diperoleh skor $28,63 \%$ dengan kategori cukup baik dan secara klasikal masih belum tuntas karena belum mencapai $85 \%$. Berdasarkan uraian tersebut maka aktivitas peserta didik perlu ditingkatkan pada siklus II. Data dari siklus I diperoleh: 1) dari 22 orang peserta didik, ada 1 peserta didik yang memperoleh skor 83-90, 2) dari 22 orang peserta didik, ada 6 peserta didik yang memperoleh skor $70-73,3)$ dari 22 orang peserta didik, ada 8 peserta didik yang memperolah skor $60-65$, dan 
4) dari 22 orang peserta didik, ada 7 peserta didik yang memperolah skor $0-50$. Berdasarkan hasil perolehan skor dari peserta didik terlihat hasil belajar peserta didik kelas XI IPS -1 MA Darul Ulum Palangka raya yang mendapat nilai ketuntasan individual $\geq 60$ berjumlah 15 orang sedangkan yang belum tuntas berjumlah 7 orang peserta didik. Ketuntasan hasil belajar secara klasikal diperoleh $68,18 \%$ karena belum memenuhi syarat ketuntasan klasikal yaitu $85 \%$ maka perlu dilakukan dan ditingkatkan kembali pada siklus selanjutnya (siklus II).

Adapun hal-hal yang harus diperbaiki adalah sebagai berikut: 1) perlu dijelaskan kembali prosedur kegiatan pembelajaran dengan menggunakan metode tutor sebaya supaya peserta didik tidak kebingungan dalam melaksanakan tugasnya, 2) perlu ditingkatkan kembali pengawasan terhadap peserta didik dalam bekerja sama dengan kelompoknya, 3) perlu ditingkatkan pemberian motivasi kepada peserta didik supaya lebih bersemangat dalam mengikuti kegiatan pembelajaran, karena metode yang digunakan tetap dengan metode tutor sebaya, 4) perlu ditingkatkan keaktifan atau keterlibatan peserta didik dalam menjawab soal latihan di depan kelas, 6) hasil belajar peserta didik dari sebelum tindakan (tes awal) sampai dengan siklus I sudah meningkat yakni dari 4 orang $(18,18 \%)$ menjadi 15 orang $(68,18 \%)$ peserta didik yang tuntas, akan tetapi masih perlu ditingkatkan, dan 6) perlu ditingkatkan dalam penyampaian materi tentang neraca lajur (kertas kerja) agar lebih mudah dipahami oleh peserta didik.
Hasil belajar yang diperoleh peserta didik siklus II pada tes akhir (post test) ini dari 22 peserta didik yang memperoleh nilai KKM 60 ke atas adalah 21 orang $(95,45 \%)$, sedangkan yang memperoleh nilai di bawah 60 adalah 1 orang $(4,55 \%)$ dan ketuntasan klasikal hasil belajar adalah 95,45\%. Aktivitas peserta didik dalam pembelajaran diperoleh persentase 90,9\% kategori baik sesuai dengan indikator ketuntasan aktivitas belajar total skor minimal 10 dengan dan skor maksimal 40 di mana pada siklus II diperoleh skor aktivitas peserta didik adalah 35,68 di atas skor minimal. Aktivitas peserta didik dikatakan meningkat apabila skor total mencapai jumlah $\geq 30$ sehingga aktivitas peserta didik meningkat dengan jumlah 35,68 sedangkan secara klasikal jumlah peserta didik yang memiliki jumlah skor $\geq$ 30 yang mencapai $40 \%$ yaitu diperoleh skor 90,9\% dengan kategori baik dan masih belum tuntas mencapai $19,18 \%$ tetapi dikatakan meningkat karena pada siklus I hanya $71,72 \%$ dan siklus II 90,9\%. Berdasarkan uraian tersebut maka aktivitas peserta didik sudah memenuhi syarat indikator keberhasilan yaitu $85 \%$ makan tidak perlu dilanjutkan pada siklus berikutnya. Indikator ketuntasan adalah: 1) dari 22 orang peserta didik, ada 11 peserta didik yang memperoleh skor $90-100,2)$ dari 22 orang peserta didik, ada 5 peserta didik yang memperoleh skor $80-87,3)$ dari 22 orang peserta didik, ada 5 peserta didik yang memperolah skor $70-78$, dan 4) dari 22 orang peserta didik, ada 1 peserta didik yang memperolah skor 57 . Berdasarkan hasil tes siklus II hasil belajar peserta didik kelas XI IPS-1MA Darul Ulum Palangka raya, yang mendapat nilai ketuntasan individual $\geq 60$ berjumlah 21 orang 
sedangkan yang belum tuntas berjumlah 1 orang. Tingkat keberhasilan ketercapaian keberhasilan pembelajaran sudah memenuhi syarat ketuntasan klasikal (85\%) yakni 95,45\% peserta didik mencapai ketuntasan belajar sedangkan peningkatan hasil belajar juga termasuk kedalam kategori sedang yakni 0,70 . Sehingga penelitian ini tidak perlu dilanjutkan ke siklus selanjutnya (siklus III). Pelaksanaan tindakan siklus II telah dilakukan secara maksimal dengan penerapan metode tutor sebayayang telah diterapkan pada peserta didik dalam proses pembelajaran, hal ini ditandai oleh: 1) hampir semua peserta didik dapat menguasai materi yang diajarkan, antusias, keaktifan, persiapan dalam mengikuti pembelajaran semakin meningkat, 2) hampir semua peserta didik mendapatkan nilai di atas KKM yang telah ditentukan oleh sekolah, meskipun ada satu orang peserta didik yang masih belum tuntas, 3) hasil belajar peserta didik pada siklus II memiliki rata-rata 84,45 dengan nilai $\mathrm{N}$-Gainnya sebesar 0,70 yang memiliki kategori sedang, dan 4) terjadinya peningkatan hasil belajar peserta didik ini terbukti dari hasil pre test tindakan pembelajaran konvesional sebesar $18,18 \%$ (4 orang) yang mencapai nilai diatas KKM, siklus I sebesar $68,18 \%$ (15 orang) mencapai nilai diatas KKM, dan siklus II sebesar $95,45 \%$ (21 orang) peserta didik yang diatas KKM.

Hasil pengamatan pada siklus I dengan rata-rata 31 yang dikategorikan cukup baik dengan persentase $71,72 \%$. pada siklus II pengamatan aktivitas peserta didik mengalami peningkatan nilai dengan rata-rata 37 yaitu termasuk kategori baik dengan persentase $90,9 \%$. Sehingga dengan menerapkan metode tutor sebaya aktivitas peserta didik mengalami peningkatan.

Nilai hasil belajar peserta didik yang dimaksud yaitu peningkatan nilai hasil belajar peserta didik kelas XI IPS-1 MA Darul Ulum Palangka raya pada mata pelajaran Ekonomi dengan materi arti Neraca lajur (kertas kerja). Berikut nilai hasil belajar peserta didik mulai dari pretest, hasil post-test siklus I dan post-test siklus II.

Berdasarkan hasil penelitian pra tindakan (tes awal) dengan persentase $18,18 \%$ (4 orang) peserta didik mendapatkan nilai lebih besar atau sama dengan 60. Hal ini belum menunjukkan ketuntasan belajar klasikal yang telah ditentukan yaitu $85 \%$ dari data di atas tersebut menunjukkan bahwa pra tindakan (tes awal) belum tercapai.

Berdasarkan hasil penelitian setelah diberikan perlakuan atau setelah dilaksanakannya siklus I ada 15 orang $(77,5 \%)$ peserta didik yang mendapatkan nilai sama dengan atau lebih besar dari 60. Hasil yang didapatkan ini masih belum mencapai ketuntasan belajar secara klasikal yang ditentukan yakni $85 \%$ dan setelah dilakukan perhitungan dengan rumus $\mathrm{N}$-Gain masih dikategorikan rendah yaitu 0,22 dari data tersebut menunjukkan bahwa siklus I masih belum bisa dikatakan berhasil.

Berdasarkan hasil penelitian dilaksanakan siklus II ada 21 orang $(95,45 \%)$ peserta didik yang mendapatkan nilai lebih besar atau sama dengan 60. Hasil ini sudah menunjukkan bhawa ketuntasan belajar secara klasikal yang ditentukan yakni $85 \%$ sudah tercapai dan kriteria $\mathrm{N}$-Gain diperoleh 0,70 yang termasuk kategori sedang. Sehingga Keberhasilan proses pembelajaran Ekonomi dengan menerapkan 
metode tutor sebaya pada siklus II termasuk kriteria tinggi dan berhasil.

Berdasarkan uraian dari pengujian hipotesis di atas dapat diambil kesimpulan bahwa metode tutor sebaya dapat meningkatkan hasil belajar Ekonomi pada peserta didik kelas XI IPS-1 MA Darul Ulum Palangka Raya Tahun Pelajaran 2013/2014

\section{KESIMPULAN}

Berdasarkan hasil penelitian dan pembahasan pada BAB IV, maka dapat diambil kesimpulan sebagai berikut: 1) terdapat peningkatan aktivitas peserta didik dalam pembelajaran Ekonomi dengan menerapkan metode tutor sebaya pada kelas XI IPS-1 MA Darul Ulum Palangka raya. Peserta didik lebih aktif dan lebih berpartisipasi dalam proses pembelajaran, Sehingga peserta didik mampu mengemukakan pendapatnya baik secara lisan maupun tertulis, 2) ada peningkatan hasil belajar Ekonomi setelah menerapkan metode tutor sebaya pada peserta didik kelas XI IPS-1MA Darul Ulum Palangka raya. Pada siklus I dapat diketahui perolehan hasil persentase pre-test terdapat peserta didik yang tuntas $18,18 \%$ (4 orang) dan peserta didik yang tidak tuntas $81,82 \%$ (18 orang) dengan nilai rata-rata yaitu 49,27. Adapun perolehan hasil pada siklus I jumlah persentase aktivitas peserta didik adalah $77,5 \%$ dengan rata-rata 3,1 sedangkan perolehan hasil belajar peserta didik adalah $68,18 \%$ dengan rata-rata 60,68 . Pada siklus II perolehan hasil persentase akitvitas peserta didik adalah $92,5 \%$ dengan rata-rata 37 sedangkan perolehan hasil belajar peserta didik adalah $95,45 \%$ dengan rata-rata 84,45 . Ada peningkatan hasil belajar dari pretest kesiklus 1 yaitu sebanyak $27,27 \%$, Ini dapat disimpulkan bahwa ada peningkatan belajar dengan menggunakan metode tutor sebaya pada pada peserta didik kelas XI IPS-1 MA Darul Ulum Palangka Raya.

\section{DAFTAR PUSTAKA}

Abu Ahmadi, \& Widodo Supriyono, (2008), Psikologi Belajar, Jakarta: CV. Rineka Cipta.

Asrori, M.(2008). Psikologi Pembelajaran, Bandung: CV. Wacana Prima.

Budiningsih, Asri. (2005).belajar dan pembelajaran.Jakarta: CV. Rineka cipta. --.(2008). Penelitian Tindakan Kelas, Bandung: CV. Wacana Prima.

Depdiknas, (2005), Undang-Undang RI No. 20 Tentang Sistem Pendidikan Nasional, Jakarta: Biro Hukum dan Organisasi Sekjen Depdiknas.

Djamarah, S,B dkk(2010), Strategi Belajar Mengajar, Jakarta: CV. Rineka Cipta. Mahmud, (2011), Metode Penelitian Pendidikan, Bandung: PT. Pustaka Setia.

Muhammad Ali (2004), Guru Dalam Proses Belajar Mengajar, Bandung: PT. Sinar Baru Algensindo.

Narbuko,Cholid, \& Achmadi, Abu. 2004. Metodologi Penelitian. Jakarta: PT. Bumi Aksara.

Puput, Pujiarti (2011).Upaya peningkatan hasil belajar hasil belajar akuntansi melalui metode tutor sebaya pada siswa kelas XI IPS 4 SMA N 1 Karanganyar, Sumber (online)22 Maret 2014.

Sardiman A. M. 2007, Interaksi Dan Motivasi Belajar Mengajar, Jakarta : PT. RajaGrafindo Persada

Slameto, (2004), Belajar dan Faktor-faktor yang Mempengaruhinya, Jakarta : CV. Rineka Cipta.

Suharsimi Arikunto dkk., (2010), Penelitian Tindakan Kelas, Jakarta: PT. Bumi Aksara. 
Sudjana, N., (2006), Tuntunan Penyusunan Karya Ilmiah (Makalah, Skripsi, Thesis, Disertasi), Bandung: PT. Sinar Baru Algensindo.

Sugiyono.(2010),Metode penelitian pendidikan (pendekatan kuantitatif, kualitatif dan $R \& D$. PT. Alfabeta Bandung.

Sukardi.(2009), Metodologi Penelitian Pendidikan, Jakarta: PT Bumi Aksara

Sukidin, dkk.(2008), Manajemen Penelitian Tindakan Kelas, Jakarta: PT. Insan Cendekia.

Suryabarata, Sumadi, (2004), Psikologi Pendidikan, Yogyakarta : PT.Rajawali Pers.

Tim Penyusun Buku Pedoman Penulisan Skripsi, (2014), Pedoman Penulisan Skripsi Edisi Tahun 2008. Palangka Raya: Universitas Muhammadiyah Palangka Raya.

Uno, Hamzah, (2007), Mengelola Kecerdasaan dalam Pembelajaran, Jakarta: Bumi Aksara 